\title{
The Dynamics of Development Communication (A Case Study: Community-Based Participatory Development Program (P3BK) Government of Bekasi City)
}

\author{
Akbar Deni Prasetyo', Choirul Fajri, ${ }^{2}$ \\ ${ }^{1}$ Communication Department, Universitas Ahmad Dahlan \\ ${ }^{2}$ Communication Department, Universitas Ahmad Dahlan \\ Corresponding Author's Email : choirul.fajri@comm.uad.ac.id
}

\begin{abstract}
P3BK is a program created by the Government of Bekasi City in order to improve the welfare of community through the development that is carrying out on community participation. communication and coordination are the important factors of the successful implementation of P3BK, so that the Government can handle the various obstacles. This research examines the dynamics of development communication that occurs in the implementation of P3BK. This research is using the descriptive qualitative method based on case studies. The data analyzed are the result of interviews, observations and documentation aimed to understand and describing the dynamics of the development communication from the government of Bekasi City through the implementation of P3BK. The result showed that communication in the implementation of $\mathrm{P} 3 \mathrm{BK}$ conducted by BKM as the sole implementing agency appointed directly by the Government of Bekasi City is very dynamic. Although facing various obstacles in the process, the implementation of $\mathrm{P} 3 \mathrm{BK}$ in Bekasi City continues to run well. BKM carries out internal and external communication through a variety of activities, such: Musrenbang, visit of BKM Bekasi City forum, distribute leaflets of development realization, etc. In addition, BKM's communication efforts in increasing public's participation succeed making the public to be actively involved in the implementation of P3BK.
\end{abstract}

Keywords: dynamic of communication, development communication, policy implementation, Government of Bekasi City

\section{INTRODUCTION}

The study of communication in implementing development policies is something that isn't new. according to Nasution (2005: 81) development is an effort made by a community to improve their standard of living. Development communication is a communication discipline in the context of developing countries, especially communication activities for planned and sustainable social 
change. In the broad sense of development communication includes the role and function of communication as a reciprocal message exchange activity between the community and the government, starting from the process of planning, implementing, and evaluating development (Nasution, 2005: 106).

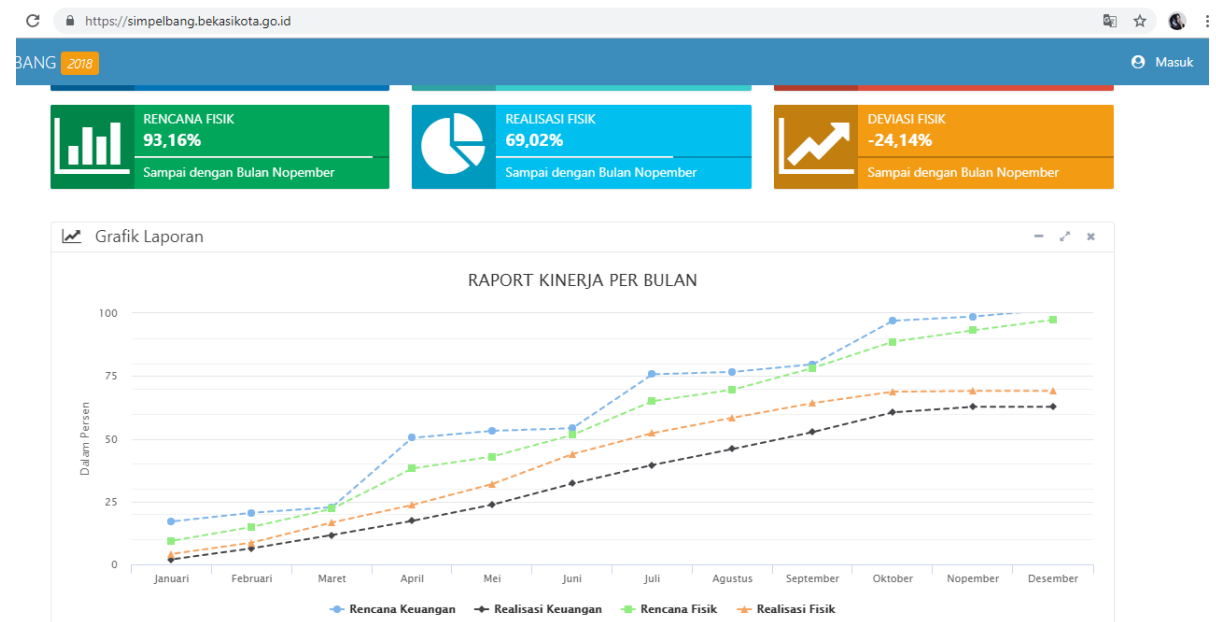

Source: https://simpelbang.bekasikota.go.id/

Bekasi City is located in the province of West Java. Nowadays, Bekasi City is a place for urban people to live and become a central place for industry. Based on the data obtained, the construction of Bekasi City experienced progress from January to September 2018 on physical realization from 58.86\%. (https://simpelbang.bekasikota.go.id/, accessed on September 24, 2018 at 19.48) and increased to $69.02 \%$ in November 2018 (https://simpelbang.bekasikota.go.id/, accessed on November 26, 2018 at 13.35). Various kinds of awards won by the Bekasi City Government in development policy. One of them is a communitybased participatory development program and becomes the spotlight of the mass media.

The Community-Based Participatory Development Program (P3BK) is a pros-community program initiated by Rahmat Effendi as Mayor of Bekasi. P3BK was an experimental program until the program finally succeed and received positive recognition from the national level. In 2018 Bekasi City Government distributed IDR.750 million for each urban village through a simultaneous development program managed by the Bekasi City BKM forum (Community Self-Reliance Agency). This amount is more than the previous year which was IDR. 500 million. The implementation of $\mathrm{P} 3 \mathrm{BK}$ is regulated in the Mayor Regulation (Perwal) 18 of 2017 which the implementation of P3BK conducted by $\mathrm{BKM}$ as the sole implementing agency appointed directly by the Government of Bekasi City. 
The implementation of $\mathrm{P} 3 \mathrm{BK}$ is not as perfect as people see it. According to Mr.Agus Sucipto as Secretary of the Bekasi City BKM Forum explained that the problems which commonly occur in implementing P3BK are communication, especially in middle management. They often make mistakes when responding to instructions. Besides that, they lack knowledge about how to use digital media too, such: social media, website, etc. This could be a problem because the public needs to know every step they took when they have to realize the program. That's why digital media needed for transparency.

Based on the information above, it can be seen that the development communication of the Bekasi City Government in carrying out P3BK runs very dynamic, there are obstacles that should be facing when implementing of a policy, makes researchers interested in researching and analyzing the dynamics of development communication that occurs in the Bekasi City Government when implementing P3BK.

\section{LITERATURE REVIEW}

\section{A. Development Communication}

Communication is the process of delivering information from one person to another. In simple words, it's a process of sharing the idea, opinions, values, etc. Meanwhile, the development is an effort undertaken by a community to improve their lives (Nasution, 2005:81). Development communication is a communication made to carry out the plan of development of a country. In a broad sense, development communication is the role and function of communication between all parties involved in development, including the government and the community. Development communication aims so that the intended community can understand, accept, and participate in carrying out development. While in the narrow sense, development communication is all efforts and methods, as well as techniques for the delivery of ideas that come from those who initiated development and are aimed at the community (Nasution, 2005: 106).

\section{B. The Dynamics of Communication}

The dynamics of communication are the process of communication between the receivers and senders of a message that can sometimes be affected by noise or not. In this case, Pearce (Pace, R Wayne \& Faules, don, F, 2010: 258) explains that communication is seen as an instrument used by humans to achieve certain purposes, including giving instructions, persuading, etc. Vertical or horizontal communication that occurs in program implementation is organizational communication that cannot be separated from group communication and interpersonal communication. According to Effendy (2009: 126) "Based on the scope, organizational communication is divided into two, namely internal communication and external communication" 


\section{Internal Communication}

Communication in an organization is the transmission of information that occurs vertically from someone with higher authority to another person whose authority is lower or commonly called downward communication. On the contrary, if information that moves from a person whose authority is lower to a higher person is called upward communication. Meanwhile, the exchange of information that occurs parallel is called horizontal.

2. External Communication

External communication is communication between the leadership of the organization or agency with the public outside the organization. According to Effendy (2009:129) "external communication consists of two lines on a reciprocal basis, that is communication from the organization to the public and from the public to the organization".

\section{Policy Implementation}

Policies without implementation will have no meaning. According to Cleaves cited in (Wahab, 2008; 187), the Implementation includes "The process of moving towards policy objectives through administrative and political steps". The success or failure of implementation can be evaluated from the standpoint of the real ability to continue the program that was designed before. Based on the Brian W. Hogwood and Lewis A. Gunn model (Nugroho, 2009: 494) to be able to implement the policy perfectly, certain conditions are needed. The conditions are:

1) External conditions encountered will not cause serious obstacles.

2) There is sufficient time and resources available.

3) Integration of sources needed

4) The policy to be implemented is based on a reliable causal relationship.

5) Causality relationships are direct and there are only a few links to them.

6) Perfect implementation requires the sole implementing agency.

7) Deep understanding and agreement on goals.

8) The tasks are detailed and placed in the right order.

9) Perfect communication and coordination.

10) There is no rejection in system administration orders. 


\section{METHODOLOGY}

This research using descriptive qualitative based on case studies that try to explain and describe the dynamics of development communication when implementing P3BK. This research is using case studies because the researcher took everything about P3BK based on factual events that happened so this research could be more focusing on an object. Case studies are approaches that can give a detailed description of the background of the problem.

This research is located at The Bekasi City BKM Forum office and Kota Baru Urban Village BKM office. The researcher took Kota Baru as focus because BKM in Kota Baru Urban Village is the best one in 56 urban village at Bekasi City and became an example for another BKM. They received an award from Mayor of Bekasi City as the best one because they know how to solve problems and initiated for made synergy forum. The synergy forum is intended to unite the government, community, and company for the development of Bekasi City. According to Zulganef (2008:162) in qualitative research, data can be obtained from interviews, observation, and documents. Interviews were conducted by the researcher with Head of the Bekasi City Development Department, Bekasi City BKM Forum Secretary concurrently chairman of Kota Baru urban village BKM, Chairperson of Kota Baru urban village LPM, and residents of Kota Baru Urban Village. Meanwhile, researchers conducted direct observations of the communication that took place while implementing P3BK. to complement the data, the researchers traced documents that could support previously obtained data.

Researchers in the ongoing research will conduct an analysis that explains the data in three stages. (1) Data reduction, namely the process of selecting data, classifying, directing, disposing of unnecessary and organizing data in such a way as to conclusions and verification. (2) Presentation of data. In this flow, all data in the field in the form of documents, interviews, and observations will be analyzed so that it can bring up a description of the dynamics of the P3BK development communication of the Bekasi City Government. (3) Concluding, is the final result of the process of data analysis, where the writer will describe, analyze and interpret the data that the author gets through the above research.

The data validation technique used is the type of triangulation. According to Sugiyono (2014: 327 ) in research to ensure the validity of the data, the research conducted with triangulation is a data collection technique and sources that already exist. With the triangulation method, the researcher collects data while testing the credibility of the data. 


\section{RESULTS AND DISCUSSION}

The researcher will explain the findings of research and analysis of the dynamics of development communication that occurs when implementing P3BK. Starting from the implementation of P3BK and continued with the dynamics of communication.

\section{A. The Implementation of P3BK}

The Community-Based Participatory Development Program (P3BK) was first conceived by Mayor Rahmat Effendi in 2012 and organized in 2013. Based on interviews with the Mayor of Bekasi in this case represented by the Head of the Bekasi City Development Department, the basic ideas for the P3BK program was the PNPM Mandiri from the central government that has stopped, then made $\mathrm{P} 3 \mathrm{BK}$ as a container for the sustainability of the development program that was previously overseen by the PNPM Mandiri.

In the Implementation of P3BK, the Mayor Regulation 18 of 2017 was made as a technical guideline for implementation and Regional Regulation 15 of 2015 legality established BKM as the sole implementing agencies of P3BK which was divided into three, namely: 1. The city level: The Bekasi City BKM Forum, 2. The Sub-district level: The Sub-district BKM Forum, 3. The Urban Village level: The Urban Village BKM. The purpose of establishing P3BK is from the community for the community. Therefore, community contributions in the form of self-help funds have greatly helped the success of the program. Also, in the process community must be actively involved and the community required to maintain and take care of the results of the development that has been realized.

Based on population census data, the population of Bekasi City is $2,334,871$ people. The population of Bekasi City is dominated by the middle population with an average age ratio of 27.12 years. The majority of the people of Bekasi City are workers, with a population of more than 15 years of 1,712,083 people and a Labor Force Participation Rate (TPAK) of $59.08 \%$ divided into $74.47 \%$ for men and 38.40\% for women ( https://bekasikota.bps.go.id/, accessed on August 26, 2019 / 13.58). Bekasi City is the central place of industry and the data described earlier reflects the Bekasi City people who are busy working in daily life so that the development of individualistic character caused the lack of interest in the youth generation to participate in P3BK. Thus, Human Resources have been dominated by the old generation in BKM when implementing P3BK.

Bekasi City Government in the last 3 years, from 2016 to 2018, has spent IDR.111,456,000,000 from the APBD to realize various P3BK development activities carried out in 56 urban villages. Based on data obtained from the Head of the Bekasi City Development Department, non-government funds collected from non-government organizations amount to IDR. 5,998,400,000 and the funds are also used in development activities. In P3BK development activities are divided into 5, namely: (1) Repair of Uninhabitable Homes, (2) Repair of Environmental Roads, (3) Repair of Drains, (4) Repair of Public Facilities, (5) 
Repair of Public Toilets. As explained earlier that the development activities carried out must meet several requirements, one of which is the budget for one development activity maximum of IDR. 50 million.

\section{B. The Dynamics of Communication}

$\mathrm{P} 3 \mathrm{BK}$ requires the community to be involved from the beginning until the end of the development process in which the role of the community includes: being involved in self-funding and realization of development and making suggestions in development planning. Because the purpose of the P3BK itself is from the community, for the community, and by the community. In the implementation of $\mathrm{P} 3 \mathrm{BK}$, a development that is informed and communicated is a development that could increase the standard of living through the activity and participation community.

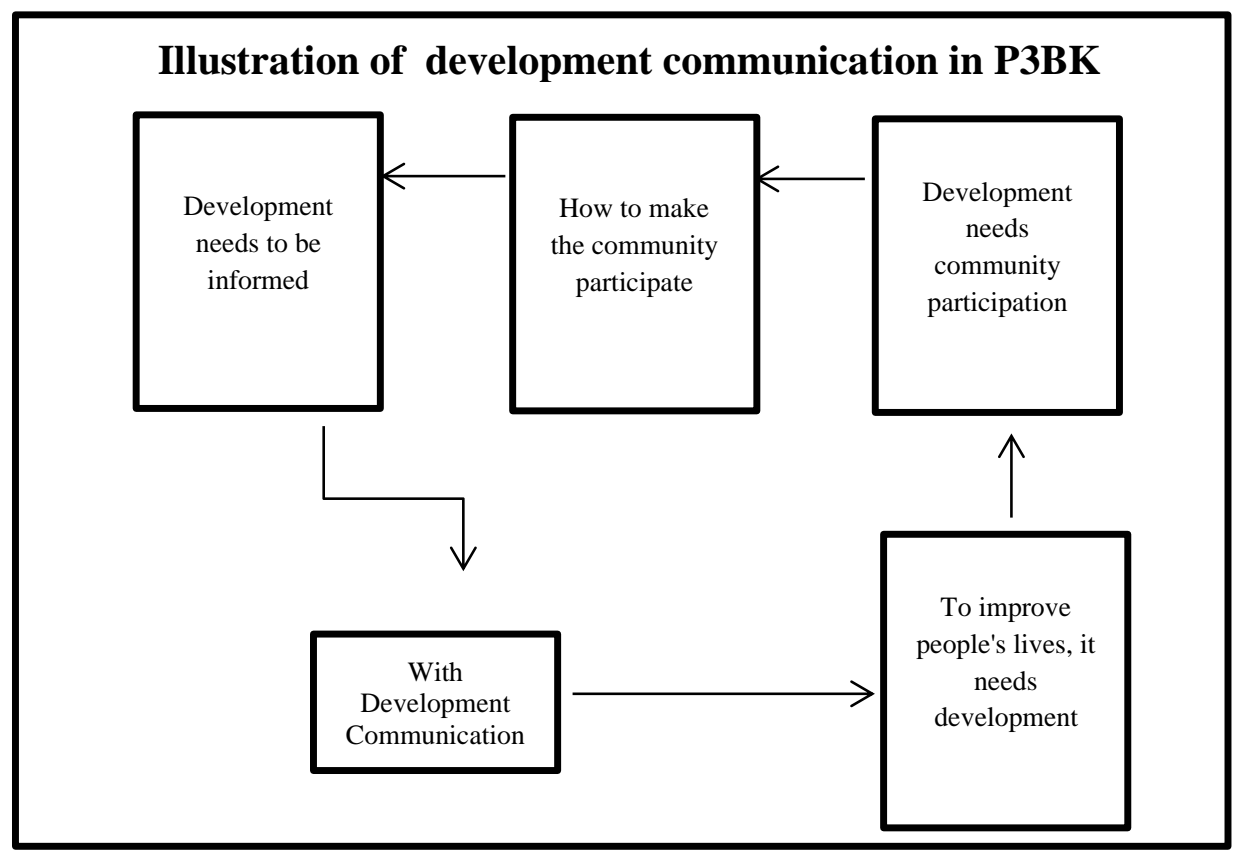

The successful development that has been carried out in the last 3 years cannot be separated from the important role of communication and coordination. Based on the stages of the process, the implementation of P3BK divided into 4 stages: pre-planning, planning, implementing and evaluating.

1) Pre-planning

At this stage, after getting the budget certainty that will be provided by the Bekasi City Government. Bekasi City BKM Forum communicates down through writing which is followed verbally to the Sub-District BKM Forum and continued to the Urban Village BKM. 
Then the Urban Village BKM conducted socialization to the community.

2) Planning

At the planning stage, community aspirations collected by the RT/RW are written in the form of a simple proposal that will be communicated during the musrenbang held by BKM. After that, proposals will be chosen to be realized. There are 3 levels of musrenbang, from the highest: 1. Bekasi City Musrenbang, 2. Sub-district Musrenbang, 3. Urban Village Musrenbang. The selection of priority proposals will be carried out at each level of musrenbang. proposals selected at the urban village level will be brought to the sub-district level until a city level.

3) Implementing

Proposals that have been decided to be realized will be brought to the plenary meeting of the DPR. Furthermore, BKM prepares a proposal and Budget Plan which later after being approved by the head of Bekasi City Development Department. The Realization will be carried out simultaneously in 56 urban villages.

4) Evaluating

After being realized, monitoring and evaluation will be carried out by the Secretary of Bekasi City. BKM itself will also conduct internal evaluations through annual or monthly coordinative meetings.

The process of communication and coordination that occurs at each stage according to researchers is very interesting. BKM as the sole implementing agent plays its role very well. The communication that BKM has done when implementing P3BK is organizational communication. According to Effendy (2009: 126) "Based on the scope, organizational communication is divided into two, namely internal communication and external communication".

\section{Internal Communication}

Bekasi City BKM forum conducted various development communication efforts in the implementation of P3BK. One of them is internal communication, various kinds of activities have been carried out to support the communication of the internal structural of P3BK. Based on research data, upward and downward communication in BKM usually formal. Downward communication within the BKM conducted through meetings such as the Musrenbang and the visit of the Bekasi City BKM Forum.

BKM communicates with verbal and written. Verbal and written methods are considered effective depending on the situation. There was a conflict between BKM during Bekasi City BKM Forum musrenbang. In solving problems like this, an appropriate method is needed. Bekasi City BKM Forum conducted a solution using the appropriate method at the time, which was a verbal and family approach. When giving direction 
down, the Bekasi City BKM Forum also uses the written method. According to Level (Pace, R Wayne \& Faules, don, F, 2010: 258), the written method is considered most effective when information is needed for future actions. The fact that we only use the written method in the implementation of P3BK it's not effective, so a combination of writing followed verbally is very needed.

The written method which followed verbally according to the researcher was effective with the current situation. it caused by the majority of the BKM members are old generations who had diverse backgrounds, tended to be retired workers and misunderstanding was considered reasonable. Therefore it requires a combination of written followed by verbal. The visit of the Bekasi City BKM Forum was intended for verbal effort. When the visit was made the team from the Bekasi City BKM Forum would explain again the letter that had been given previously.

Upward communication within the BKM generally occurs when aspirations of the community are received by the urban village BKM and submitted to the sub-district BKM Forum which can finally be accepted by the Bekasi City BKM Forum. This process is through the written method followed verbal as well as the downward communication previously described. That is, each proposal must be attached in written then followed verbally. In implementing P3BK, upward communication only can be seen in the context of development proposals. In reality, higher authorities should know regarding complaints in implementing P3BK by the urban village BKM besides development proposals. The visit of the Bekasi City BKM Forum which initially aimed at downward communication now becomes more flexible and can solve those problems.

Horizontal communication in the implementation of P3BK is informal in daily life between the Sub-district BKM Forum or between the Urban Village BKM. Informal communication makes interpersonal relationships getting closer. Horizontal communication made by BKM is an effort to coordinate and avoid misunderstandings between BKM in sub-district or urban village.

\section{External Communication}

The implementation of $\mathrm{P} 3 \mathrm{BK}$ carried out by BKM requires a communication strategy and approach so that the community can be involved in development. The ongoing communication must be reciprocal between the community and BKM. According to Effendy (2009:129) "external communication consists of two lines on a reciprocal basis, that is communication from the organization to the public and from the public to the organization".

a. Communication from the organization to the public 
The communication strategy undertaken by BKM to the public by using printed media such as brochures, leaflets, banners, etc. At the beginning of the communication between BKM and the community, it was only a meeting with information that was not distributed comprehensively. Then, bad information that is doubtful is circulating in the community. Therefore, BKM chose to use communication media as mentioned above to be more informative and transparency about the realization of development. leaflets that distributed contain the telephone numbers of BKM members who will provide the information needed by the community. Besides the community, BKM communicates with companies to get involved in P3BK through meetings that have been previously held, the company is Bali Fiber Internet Ltd. The synergy forum is the result of good communication between BKM and the company, so the company provides sponsors in the $\mathrm{P} 3 \mathrm{BK}$ development activities

b. Communication from the public to the organization.

In implementing $\mathrm{P} 3 \mathrm{BK}$, communication from the public to the organization can be carried out during urban village level musrenbang attended by community leaders, RT and RW. The community can provide aspirations for development through RT / RW. Proposals received by the RT / RW will be made a simple budget and proposal which can later be discussed with the urban village BKM during the musrenbang. The lack of mediums of communication between the community and the organization is the lack of P3BK implementation even though the one-way information provided by BKM is going well.

Mr. Nasrudin as a community leader in Kota Baru urban village said that the community needed something new from BKM such as social media or website to talk. The lack of mediums provided by BKM for the public to communicate with BKM is an important factor that can be obstacles for the implementation of P3BK. The telephone number in the leaflet that given by BKM to the community is a way of temporary settlement that can be given to the community who want to give their suggestions and criticisms to BKM or get information about P3BK.

\section{CONCLUSION}

The Community Based Participatory Development Program (P3BK) is a program that aims to involve the community in development that takes place in the City of Bekasi. In implementing P3BK the role and function of communication are very important to attract the interest of the community to participate. BKM as the sole implementing agency has made various internal and external communication efforts to achieve these goals. Community involvement 
in the last three years has been seen actively in the implementation of P3BK. the people who participated in the development described the success of the communication carried out by BKM. The long process of implementing P3BK has made BKM getting better to understand the way of communication in solving various obstacles.

Communication that occurs in the implementation of P3BK runs very dynamic, it can be seen when BKM faces problems in communication and coordination on the part of middle management, BKM makes a communication agenda such as the visit of the Bekasi City BKM Forum which aims to solve these problems. Aside from being internal, BKM has also succeeded in achieving the goals of involving the community in the program by conducting various agendas and using conventional communication media to achieve a climate of good communication with the community so that the community is willing for contributions to development.

$\mathrm{P} 3 \mathrm{BK}$ is one of development communication strategy carried out by the Bekasi City Government in increasing the sense of community awareness to be involved in development activities aimed at welfare as well as maintaining and caring for the results of development.

\section{REFERENCES}

\section{Book}

Effendy, Onong Uchyana. (2009). Ilmu Komunikasi Teori dan Praktek. Bandung: PT. Remaja Roesdakarya.

Nugroho, Riant. (2009) Public Policy (edisi revisi. Jakarta: PT. Elex Media Komputindo.

Nasution, Z. (2005). Komunikasi Pembangunan: Pengalaman Teori dan Penerapan. Edisi revisi. Rajawali Pers: Jakarta.

Pace, R Wayne \& Faules, don, F. (2010). Komunikasi Organisasi: Strategi Meningkatkan Kinerja Perusahaan. Terjemahan: Deddy Mulyana. Bandung: Remaja Rosdakarya.

Sugiyono. (2014). Metode Penelitian Kuantitatif dan Kualitatif. Bandung: Alfabeta.

Wahab, Abdul, Solichin. (2008). Analisis Kebijakan: Dari Formulasi ke Implementasi Kebijakan Negara Edisi Kedua. Jakarta: Bumi Aksara.

Zulganef. (2008). Metode Penelitian Sosial \& Bisnis. Edisi Pertama. Yogyakarta: Graha Ilmu. 
(ution and Humamities Research, volume 423

\section{Website}

https://bekasikota.bps.go.id/

https://simpelbang.bekasikota.go.id/ 